\title{
Diferentes como só nós. O associativismo GLBT português em três andamentos
}

Different Like Us. Portuguese LGBT associations in three tempos

Différents seulement comme nous. L'associativisme GBLT portugais en trois

marches

\section{António Fernando Cascais}

\section{(2) OpenEdition}

Journals

Edição electrónica

URL: http://journals.openedition.org/rccs/868

DOI: $10.4000 /$ rccs. 868

ISSN: 2182-7435

Editora

Centro de Estudos Sociais da Universidade de Coimbra

Edição impressa

Data de publição: 1 Dezembro 2006

Paginação: 109-126

ISSN: 0254-1106

Refêrencia eletrónica

António Fernando Cascais, « Diferentes como só nós. O associativismo GLBT português em três andamentos », Revista Crítica de Ciências Sociais [Online], 76 | 2006, colocado online no dia 01 outubro 2012, criado a 20 abril 2019. URL : http://journals.openedition.org/rccs/868 ; DOI : 10.4000/rccs.868 


\section{ANTÓNIO FERNANDO CASCAIS}

\section{Diferentes como só nós. O associativismo GLBT português em três andamentos}

O presente texto toma como eixo de análise o modo como a diferença específica da formação social portuguesa determina e se exprime na sociogénese do associativismo GLBT nas três últimas décadas. É possível traçar uma periodização dele em três estádios, à qual deve atribuir-se sobretudo um valor heurístico: o primeiro de 1974 até 1991, que pode dividir-se em duas fases, uma anterior e outra posterior ao surgimento da epidemia de Sida no nosso país; o segundo, entre 1990-1991 e 1995-1997; e o terceiro, de 1997 até ao presente. A produção de conhecimento sobre o associativismo GLBT tem ainda de se articular com duas outras pesquisas: sobre os seus detractores e inimigos, antigos e neófitos, e sobre a comunidade que o associativismo representa ou de que emerge, com uma história, uma identidade e uma cultura que explicam as razões da adesão ou da resistência a ele.

À crítica queer não pode deixar de lhe fugir o pé para o divismo. Humildemente o admito e reconheço, bonnêteté intelectuelle oblige. Eis porque da opulência da Loren ( $\operatorname{sim}$, essa Sofia, nada a ver com a bizantinice da hagia sofia) herdei a minha graça, e na valorosa Dietrich (essa Marlene, a única), sempre pronta, como eu, a indagar o que é feito das flores, inspirei o meu patronímico. Moi? Queerérrima. Assumida. Out.

SOPHYA CRITICH, in Tratado dos maus objectos (em preparação)

O presente texto toma como eixo de análise o modo como a diferença específica da formação social portuguesa determina e se exprime na história do movimento associativo gay, lésbico, bissexual e transgénero (GLBT) no nosso país nas três últimas décadas. As considerações aqui tecidas devem ser tidas como preliminares - e, portanto, sujeitas sempre a revisão crítica a quaisquer futuras pesquisas, necessariamente muito mais vastas e aprofundadas, sobre o papel e o sentido do associativismo na história, na cultura e na identidade das comunidades GLBT portuguesas. 


\section{Em vésperas do associativismo}

Embora a comunidade já tivesse principiado a constituir-se há muito, não existe movimento associativo gay, lésbico, bissexual ou transgénero organizado em Portugal antes da Revolução de 25 de Abril de 1974. Não o teria permitido a ausência de liberdades democráticas, que são condição essencial, embora não única, da sua emergência. Nem por isso - et pour cause a simples criação de liberdades formais, jurídico-políticas, de associação e de expressão, bastou para o surgimento de movimentos autónomos duradouros, pelos quais teria que esperar-se ainda cerca de duas décadas. Por outro lado, a sociogénese do movimento obedece ao padrão comum nos países da Europa, e nomeadamente do Sul, ocorrendo no seio da tradição e com os materiais do património emancipatório das esquerdas.

Ainda na época da ditadura, as oposições nunca incluíram a emancipação homossexual na sua agenda e só muito lateralmente a sexualidade, sobretudo quando inserida no âmbito mais lato do que então se chamava a "questão da mulher", mas de um ponto de vista quase exclusivamente trabalhista e laboral, e, mais tarde, no âmbito do que se entendia como a "questão da juventude", introduzida sobretudo pelos movimentos estudantis. Com efeito, a escassa receptividade ao movimento homossexual proviria de alguns intelectuais ou estudantes das gerações mais jovens (mas não das gerações veteranas da oposição, sobretudo as ligadas ao Partido Comunista) que no exílio no estrangeiro puderam testemunhá-lo directamente. Do mesmo modo, a participação nas actividades políticas oposicionistas de pessoas, inclusive figuras públicas, declarada ou reconhecidamente homossexuais, que as houve, de maneira alguma significava que a agenda genericamente antifascista, anticolonialista e, nos sectores marcadamente marxistas, anticapitalista, fosse suficientemente aberta para admitir, nem sequer no seio da sua "questão cultural", qualquer veleidade de emancipação homossexual. Com efeito, a esquerda portuguesa passou em grande medida ao lado das transformações culturais que ocorriam nos outros países nas décadas de 1960 e 1970, que foram fundamentais para o processo de renovação das esquerdas europeias. Após a revolução, o quadro de grande atraso no desenvolvimento do país só contribuiria para afunilar a acção política no sentido de erguer um Estado social, o que, quanto mais não fosse, bastaria para que a margem para outro tipo de reivindicações se tornasse assim mínima e sempre precária e em permanente ameaça. As preocupações políticas eram de tal modo outras que tombavam de encontro a um muro de incompreensão os raríssimos ecos do empunhamento da emancipação homossexual pela esquerda radical no Maio de 68 em França. Identicamente, ou mais ainda, era nula a notícia da revolta de Stonewall, 
em $1969^{1}$, e das primícias do actual movimento gay e lésbico nos Estados Unidos da América. De resto, este era já herdeiro de uma tradição provinda da fase homófila do associativismo. Do ponto de vista associativo (que não cultural, pois o argumentário homófilo foi utilizado na defesa de António Botto), esta fase é completamente desconhecida em Portugal e o associativismo apenas surgirá entre nós num momento em que o próprio estádio gay e lésbico do movimento tinha atravessado uma longa evolução nos contextos norte-americano e norte-europeu de origem e, por isso, desprovido da dimensão auto-reflexiva que ele foi adquirindo nestes.

Por outro lado, o quadro nacional merece comparação com aquele que lhe estava mais próximo, a Espanha da transição para a democracia (Mira, 2004: 421-425). No caso espanhol, existiam embriões de associativismo gay clandestinos nos últimos anos da ditadura, integrados na oposição antifranquista e precipitados pelo agravamento da repressão na sequência da promulgação da Lei de Periculosidade e Reabilitação Social, em 1970. Além disso, o movimento homossexual espanhol surge associado, em particular, ao renascimento e à efervescência cultural que envolveram as movimentações políticas autonomistas da Catalunha, o mesmo ocorrendo, ainda que com expressão consideravelmente inferior, no País Basco. Tanto explica que viesse posteriormente a ser objecto de apoio e incentivo dos governos das Comunidades Autónomas, ou seja, portador de um capital cultural e de credibilidade histórica, social e política, que lhe possibilitaria uma afirmação e uma instalação precoce no regime democrático, facto de todo desconhecido na sociedade portuguesa do pós-25 de Abril.

Não existia em Portugal nada de semelhante a essa cultura política de esquerda receptiva à emancipação homossexual ao ponto de, mais cedo ou mais tarde, lhe integrar as principais reivindicações na sua própria agenda. É precisamente neste ponto que tem início a descolagem entre a nossa realidade histórica e a do país vizinho, que se aproxima de modo crescentemente célere do estado de avanço das sociedades da Europa do Norte. Nem por isso as primeiras expressões políticas do movimento homossexual português poderiam ter deixado de nascer claramente posicionadas à esquerda, mas, e por isso mesmo, portadoras de uma ambiguidade intrínseca: tomando

\footnotetext{
${ }^{1}$ De 27 para 28 de Junho de 1969, a polícia efectuou uma rusga ao bar Stonewall Inn, em Greenwich Village - Nova Iorque, cuja clientela era sobretudo composta por pessoas gays, lésbicas, bissexuais e transgéneros, com uma forte incidência em minorias étnicas. Face a essa rusga registaram-se reacções violentas que prefiguraram um motim urbano de vários dias. Este evento desencadeou o crescimento de associações e iniciativas LGBT um pouco por todo o mundo e, desde então, Stonewall e o 28 de Junho constituem símbolos de resistência à heteronormatividade. Mais informações sobre este tema disponíveis em http://en.wikipedia.org/wiki/Stonewall_riots.
} 
como modelo de referência política e cultural um sector que começou por o enjeitar numa primeira fase.

\section{Uma composição em três andamentos}

Com efeito, é possível esboçar, a traço grosso e com a ressalva de não haver demarcação rígida entre eles, uma periodização em três estádios do associativismo GLBT em Portugal: o primeiro de 1974 até 1990, que pode dividir-se em duas fases, uma anterior e outra posterior ao surgimento da epidemia de Sida no nosso país; o segundo, entre 1990-1991 e 1995-1997; e o terceiro, de 1997 para cá. A ruptura mais marcante é a que separa os dois primeiros períodos do mais recente. Esquematicamente, teríamos:

1974-1990 - primeiro período (com um eixo em meados da década de 80) 1990-1991 - período de transição, com características mistas 1991-1994 - segundo período

1995-1997 - período de transição, com características mistas 1997 ao presente - terceiro período

\section{Primo - "Largo"}

As primeiras manifestações de um movimento homossexual embrionário são fruto da iniciativa de escassas pessoas individuais, que se identificam decididamente com a(s) esquerda(s), mas dissociadas das organizações partidárias e sindicais em cujo interior as identidades e as reivindicações dos homossexuais não encontram qualquer receptividade nem, consequentemente, possibilidade de expressão. Ter-lhes-ia sido sempre completamente impossível, como foi, inflectir a seu favor a dinâmica interventiva das forças da esquerda que paternalistamente lhes menosprezavam os conteúdos reivindicativos ou lhes recusavam mesmo quaisquer formas de afirmação autónoma. As esquerdas conservaram em larga medida características arcaizantes moldadas no decurso de uma longa oposição a um regime ditatorial cuja acção se pautava, ela própria, pela manutenção programática do quadro de atraso estrutural do país e do seu papel de intermediação, enquanto potência colonial, no âmbito das relações mundiais. A esquerda partidária e sindical, sobretudo comunista, dotada de uma estrutura organizada que lhe permite implantar-se de imediato e adquirir uma ampla influência, define-se em função do ruralismo tradicional e do industrialismo do século XIX e é herdeira directa da cultura neo-realista que, como logo o notou Eduardo Lourenço (1978), veicula uma imagem populista idealizante do povo português que prolonga e chega a reforçar, mas não subverte, o nacionalismo do Estado Novo. 
À luz do modelo prevalecente de racionalidade materialista-histórica da luta de classes como motor da história conducente à sociedade socialista, a "questão homossexual" só poderia ser verdadeiramente esclarecida numa futura sociedade sem classes. Entretanto, a ideia de um combate homossexual era percebida, na melhor das hipóteses, como divisionista, porque distraía os trabalhadores e os militantes dos objectivos fundamentais da sua luta, fazendo o jogo do inimigo e vulnerabilizando-os perante ele, e como desmoralizadora, porque retiraria energias necessárias à transformação revolucionária da sociedade, de que o proletariado representa a vanguarda. A luta dos homossexuais aparece assim como essencialmente desmobilizadora, ultra-minoritária e sem repercussão nem proveito para lutas mais alargadas de valor social e político geral, uma ilusão pequeno-burguesa e/ou esquerdista. Na pior, mas muito comum, das hipóteses, a homossexualidade é encarada como uma demonstração eloquente da decadência burguesa, e os homossexuais como inimigos de classe, e inclusive como prática nazi, assimilando-se perversão política a perversão sexual: caso do estereótipo aplicado aos leather que revela, no entanto, outro obstáculo intransponível à assimilação da emancipação homossexual, que é a incomensurabilidade entre o discurso revolucionário e o léxico erótico homossexual em geral, que não apenas o leather ou outro qualquer (Cascais, 2003b). Com efeito, do ponto de vista da moral revolucionária que mitifica a figura do proletário impoluto e expoente das virtudes másculas, o homossexual só é inteligível como a antítese daquele e qualquer afirmação da sexualidade percebida como equivalente aos excessos sumptuários da burguesia, ao consumo desenfreado e ao esbanjamento típico de uma cultura do parasitismo social, incompatível com a frugalidade e a contenção impostas pela disciplina do trabalho e da produção e em tudo contrário ao ascetismo proletário que mais não faz do que reduplicar, secularizando-o, o ascetismo católico. De resto, e além do nexo subterrâneo com este último, a (pretensão à) autoridade moral revolucionária também acaba por fazer passar por virtude, reproduzindo-os e reforçando-os por isso mesmo, o heterossexismo e a homofobia dominantes - termos críticos inexistentes e, logo, incompreensíveis à época.

Mais latamente, a reivindicação de uma diferença identitária surge como suspeita ao igualitarismo fundacional do pensamento de esquerda de matriz iluminista, que o marxismo apenas veio reforçar, e como uma questão que confunde de maneira equívoca a destrinça binária clássica entre esfera pública e esfera privada. Tanto assim era que a "questão homossexual" (e que deploráveis ecos ela tem de uma "questão judaica"!) passava por ser assunto de mera regulação jurídica, completamente diluída no reconhe- 
cimento genérico e inespecífico de mais ou menos direitos, liberdades e garantias aos cidadãos em geral, independentemente da sua orientação sexual - termo então completamente ausente, mas que, por marcar uma especificidade irredutível, continua hoje a ser fonte de escândalo para todos quantos, de uma ponta à outra do espectro político, vêem na reivindicação de direitos a exigência de abusivos privilégios. É deste modo que, por um lado, a persecução denodada da respeitabilidade burguesa, por parte da esquerda democrática também não proporcionava alternativa à (im)possibilidade de expressão da emancipação homossexual e que, por outro lado, nas raras ocasiões em que esta era tematizada nalgumas publicações ligadas à esquerda radical, era invariavelmente enquadrada na "libertação do quotidiano" e na "transformação da vida", destituídas de conteúdo político preciso. Curiosamente, ou nem tanto, é neste último âmbito que pela primeira vez são introduzidos, no nosso país, os debates sobre a medicalização da homossexualidade e do desvio, do papel de controlo social da medicina e da psiquiatria e da contestação aos paradigmas médicos dominantes. Isso constituiu um primeiro desafio à cultura científica das esquerdas portuguesas, demasiado marcadas ainda pelo republicanismo positivista e que partilham tudo quanto é representação estereotipada da homossexualidade com o resto do espectro político e da sociedade em geral, mas também da universidade que, numa época que antecede de muito a emergência dos estudos de género, gay, lésbicos e queer no panorama académico nacional, é quase completamente estanque ao ventilar destes temas. Do mesmo modo, é consabido que o feminismo português se mostrou refractário à integração do lesbianismo (lembre-se que lésbica era um termo tido por insultuoso numa época em que as mesmas se percebiam como "homossexuais femininas" e os homens como "homossexuais masculinos") no seu projecto emancipatório, como sempre o reiteraram as lésbicas e o acabaram por reconhecer as feministas, posições resumidas recentemente por Amaral e Moita (2004: 101).

Mas, facto absolutamente determinante, durante este período, os homossexuais são presa inerte e vítima muda das representações sociais e políticas, culturais, mediáticas e científicas; objectos de discurso e não sujeitos de palavra, como notavelmente demonstrou Michel Foucault (1977). Mesmo quando são auscultados, é invariavelmente para os transformar em matéria-prima de ilustração biográfica das opiniões sociais e das representações prevalecentes. A única excepção com notoriedade pública, e notável por isso, foi então a de Guilherme de Melo, e não porque a assumpção pública fosse inexistente, mas porque ele foi o primeiro a fazê-lo em nome de uma entidade colectiva - "os homossexuais" - ainda que esta fosse até aí prati- 
camente invisível enquanto tal. Tanto os seus defensores como os seus detractores se confrontam com uma ausência, a do único interlocutor directamente interessado, o movimento associativo, então praticamente inexistente ou inexpressivo, com poucas excepções, de resto votadas à efemeridade. Tal é o caso do Movimento Homossexual de Acção Revolucionária (MHAR), logo em Maio de 1974, que não sobrevive à reacção pública do General Galvão de Melo, membro da Junta de Salvação Nacional e que cedo representa, no interior dela, a reacção de direita ao 25 de Abril. Esta situação de inassimilabilidade do movimento homossexual pelas forças políticas de esquerda mantém-se mesmo quando a influência destas principia a declinar na sociedade portuguesa. É nesse contexto, caracterizado ainda pelo facto de alguns muito jovens militantes partidários homossexuais se decepcionarem definitivamente com a possibilidade de abertura das suas organizações, que surge, em 1980, o Colectivo de Homossexuais Revolucionários (CHOR), conseguindo juntar algumas centenas de pessoas na sua reunião inaugural na sede da Culturona, organização de intervenção cultural em cujo seio tinha nascido e com cujo precário apoio contava. O CHOR pouco lhe sobrevive, porém, tendo feito a sua derradeira aparição pública por ocasião dos Encontros "Ser (homo)sexual", realizados pelo Centro Nacional de Cultura em 1982, onde foi lançado o primeiro texto de reflexão teórica sobre o movimento em Portugal (Cascais, 1983).

A ênfase com que me alongo sobre o que constituía, à época, o discurso emancipatório da esquerda prende-se com o facto de ele ser o único disponível para a emancipação homossexual se exprimir (embora de modo algum o único em que se pode exprimir a homossexualidade), mas que de facto levantava dificuldades intransponíveis a essa expressão, as quais só poderiam ser ultrapassadas por intermédio de uma reformulação radical dele. No plano teórico, Michel Foucault teve um papel fundamental na desmarxização da linguagem emancipatória, mas a recepção do pensamento foucauldiano nesse tempo (Cascais, 1988, 1994), em Portugal, limitava-se a escassíssimos círculos académicos e nunca teve influência directa no associativismo GLBT português, que só começaria a assimilá-la de forma superficial e por vias indirectas muito mais tarde, no momento em que surgem os primeiros estudos gay, lésbicos e queer (Cascais, 2004). Com efeito, o processo dessa reformulação, que se encontra longe de estar concluído no nosso país, é contemporâneo, no seu início entre nós, da adesão à Comunidade Europeia, do cavaquismo e do surgimento da epidemia de sida e, como é evidente, não poderia deixar de ser também obra, e constitui um dos adquiridos, do movimento associativo GLBT. A primeira fase deste estende-se de 1974 a 1991, quando surge a primeira associação duradoura, 
o Grupo de Trabalho Homossexual (GTH) do Partido Socialista Revolucionário, mas tem um eixo temporal naqueles acontecimentos, que se verificam todos em meados da década de 1980 e dividem a primeira fase do associativismo GLBT em dois períodos, dos quais já descrevi o primeiro.

Para além da inexistência de movimento associativo homossexual, facto comum aos movimentos feministas (Amaral e Moita, 2004: 101) e que se enquadra no declínio geral da fase eufórica e voluntarista do associativismo cívico e cultural (que não estritamente político-partidário), a partir de 1982 começa a fazer-se sentir de maneira cada vez mais omnipresente uma atmosfera de refluxo generalizado, pese o facto, sobretudo simbólico, porque havia anos que a lei tinha deixado de ter aplicação prática, da descriminalização da homossexualidade no Código Penal promulgado naquele mesmo ano. Praticamente desaparecem as expressões mais visíveis da vida gay que se desenvolvia desde 1974 em Lisboa, que, com os únicos bares então existentes e os múltiplos locais de encontro, se tinha tornado uma referência para gays e lésbicas que aí acorriam de todo o país, onde se começava a fixar de forma permanente uma massa considerável de pessoas e onde estavam em gestação formas de sociabilidade que haveriam de constituir uma das bases de uma comunidade propriamente dita. Desaparece por completo a pouca visibilidade pública de gays e lésbicas fora de Lisboa. Muito mais do que quaisquer manifestações virulentas de intolerância homofóbica, a crise económica e social contribuía de maneira decisiva para o desencanto generalizado relativamente às formas tradicionais de participação política, mas também, e ao mesmo tempo, para dissuadir actividades cívicas demasiado afastadas das preocupações do quotidiano. Com a aproximação da adesão de Portugal à União Europeia, oficializada em 1986, gera-se um clima de expectativa de acesso ao adquirido europeu, não só relativamente aos indicadores de progresso humano, mas também, e de forma sobremaneira clara e ostensiva entre gays e lésbicas, ao seu adquirido cultural e jurídico, por meio da transposição das legislações mais avançadas para a portuguesa (Santos, 2005: 145, 176). De resto, este é um facto característico das sociedades semiperiféricas como a portuguesa. A partir de 1987, os governos de Cavaco Silva só contribuíram para confirmar e intensificar a expectativa relativamente à superação dos atrasos estruturais nacionais, mas também tiveram o efeito de remeter as forças de esquerda para uma posição defensiva e de necessidade de repensar as suas concepções e as suas práticas, facto que - é imperativo reconhecê-lo - permitiu torná-las mais permeáveis a temas como a emancipação homossexual, num primeiro momento, e, bastante mais tarde, deu margem a que os defensores dela pudessem exprimir-se no seio das próprias formações partidárias (do PS, do PCP e do BE). 
No entanto, os "anos de chumbo", que se adensavam desde a notícia do surgimento da epidemia de sida, agravam-se com a notícia da identificação dos primeiros casos em Portugal, até que a morte de António Variações, em 1986, é experienciada como tragédia colectiva que se abate sobre a comunidade gay.

\section{Secondo - "Andante Con Moto"}

A epidemia de sida tem um papel charneira na emergência do associativismo GLBT em Portugal, facto generalizadamente reconhecido e que confirmam Almeida (2004: 251), Cascais (1997: 23-24) e Santos (2005: 99-102), mas há que o esmiuçar. Nos EUA, a resposta da sociedade à sida teve por modelo a organização do combate à epidemia montada no seio das comunidades gay, as mais atingidas, pelo menos inicialmente, e também as mais preparadas por um já considerável e rico passado de organização comunitária e luta política. Este modelo, próprio das sociedades centrais, alargou-se aos países onde existia tradição associativa e comunidades organizadas e permitiu fazer face ao backlash que viria a fazer-se sentir na sequência do impacto inicial da sida. Em Portugal, aconteceu precisamente o contrário: foi a organização do combate à sida que criou o movimento associativo e não se pode falar de um backlash porque, quanto mais não seja, também pouco ou nada havia em relação a que recuar, nem forças contrárias contra as quais resistir na defesa de conquistas. $\mathrm{O}$ movimento associativo português, mas, de modo mais geral, a visibilidade de uma comunidade gay que tem nele um dos seus pilares (e que, logo, não se encontra completamente constituída sem ele), ganha impulso no seio de um processo mais vasto de combate à epidemia de sida e em cuja dinâmica começa por se integrar, dela tirando partido de forma notável, antes de se poderem vir a autonomizar dela, constituindo a sua própria. É nesta medida que a sociogénese do associativismo gay em Portugal confirma a situação de semiperiferia da formação social portuguesa, inicialmente teorizada por Boaventura de Sousa Santos (1992, 1996), na esteira de Immanuel Wallerstein, e cuja aplicação à comunidade GLBT se deve a Ana Cristina Santos (2005). O surgimento do associativismo gay no quadro do combate à epidemia, não é, de resto, exclusivo da realidade nacional, mas antes comum, e típico, de outras sociedades semiperiféricas.

Entre nós, desde cedo é possível notar a participação de gays nas organizações não governamentais de luta contra a sida, mas estas eram fruto da iniciativa de elites de técnicos e profissionais de saúde, psicólogos e uma ou outra figura pública. Esta situação não será totalmente desprovida de custos, visto que a dupla filiação de alguns dirigentes associativos gay relativamente àquelas organizações não governamentais gerou inicialmente 
algumas situações de ambiguidade e de conflito de interesses sempre que algum paternalismo delas levou a tentativas de ingerência na política associativa. Trata-se de um modelo de participação cívica já bem conhecido pelo menos desde Tocqueville, que descrevera como as iniciativas reformistas e de intervenção política em geral partiam na Europa das elites esclarecidas (políticas, económicas e sociais, culturais), que se comportam como representantes de outrem que neles delega, formal ou tacitamente, os próprios interesses, ao contrário do modelo basista prevalecente nos EUA, onde aquelas tinham por protagonistas associações de cidadãos anónimos que se representam antes de mais a si próprios, elegendo os seus delegados entre os pares.

Em Portugal, o discurso do combate à epidemia foi encabeçado por terceiros não ligados à comunidade gay, e nomeadamente pela classe médica, cuja autoridade, tanto científica como social, se mantinha intacta. A luta contra a discriminação dos seropositivos e doentes pôs invariavelmente a tónica no bem comum, sem se assumir como porta-voz dos seus interesses particulares e sem sequer lhes fazer referência explícita, antes os diluindo no âmbito mais vasto dos direitos humanos e de cidadania. Além disso, o tempo que a epidemia demorou a ser clinicamente identificada no país permitiu, sobretudo no respeitante à classe médica, mas também à classe política e aos meios de comunicação, que não se repetissem os estragos causados noutros lugares pela categorização inicial, entretanto revista, dos "grupos de risco", onde avultavam os homens homossexuais.

Tudo isto contribuiu para que: a luta contra a sida surgisse desvinculada do discurso emancipatório gay, o que acabou por contribuir para a sua aceitabilidade e preparar a reacção inicialmente neutra ao movimento associativo, cuja postura nunca assume, entre nós, a radicalidade de que foram expoentes os grupos $A c t-U p$; a prevenção tivesse sido assumida como responsabilidade social por múltiplas instâncias, para além da classe médica, desde o poder político às organizações não governamentais e aos meios de comunicação, e que estas passassem a pautar-se por preocupações de correcção política, até aí quase inédita relativamente aos gays, o que teve por efeito uma espécie de reconhecimento oficial da existência da comunidade gay e como que uma caução dos seus comportamentos sexuais - visibilidade e caução cuja importância também se mede pelas reacções ultrajadas de algumas entidades como a hierarquia da Igreja Católica; embora não menos virulentas, as posições doutrinárias desta passaram a ficar desse modo sujeitas a desautorização pública, desafio reiterado e risco permanente de encurralamento em atitudes defensivas e rígidas, generalizadamente percebidas como fundamentalistas e fanáticas; com efeito, é igualmente a homofobia 
e o heterossexismo tradicionais da sociedade portuguesa que se vêem confrontados, e silenciados, pela primeira vez, por um discurso de autoridade que se expressa na luta contra a sida; enfim, o movimento associativo emergente dispunha, portanto, de um capital de respeitabilidade - isto é, como interlocutor credível - que, tudo leva a crer, não teria granjeado por outras vias e aproveita de uma dinâmica emancipatória, que até hoje não foi realmente quebrada, e que tolhe a margem de manobra, a audiência pública e a eficácia dos inimigos, os quais, não obstante, não deixa de manter, mas que só conseguem recuperar a sua sanha a partir do momento em que o movimento associativo ergue outras bandeiras com força suficiente para as defender de forma consequente, o que não ocorrerá realmente antes de 1997. Do ponto de vista da periodização que apresentei no início, o processo que tenho estado a descrever decorre sensivelmente entre o surgimento da epidemia de sida e 1990-1991, data em que se constituem a revista lésbica Organa e o Grupo de Trabalho Homossexual (GTH), que tomo como marco arbitrário que conclui o processo do impacto inicial da sida na comunidade.

Nem por isso se deve entender que a epidemia de sida se reduz ao momento do kairos para o associativismo gay (e GLBT em geral) português. Essa oportunidade única teve o seu preço de sangue com um extenso martirológio, cuja importância nunca foi devidamente apreciada pela investigação científico-social num país possuidor de um património mítico-religioso como o nosso e a que também não posso dar seguimento aqui. De modo muito superficial, adiantaria que se trata do fenómeno que, por excelência, retira argumentos ao adversário numa cultura, como a nossa, em que a afirmação pública de convicções passa menos pelo debate doutrinário e a argumentação racional do que pela exemplaridade heróica (com a sua contrapartida, que é a sedução estética). Paradoxalmente, ou talvez nem tanto, esse constitui um possível factor explicativo (para além dos apontados atrás) para o modo particular como se exprimiram, entre nós, fenómenos de tamanha amplitude e tão profundas repercussões noutras paragens (sobretudo nos EUA), como a discriminação dos seropositivos e doentes, a culpabilização das vítimas, ou o pânico sanitário que sempre acresce ao pânico moral. De modo porventura demasiado sucinto e sujeito a aprofundamento ulterior, adiantaria que as características da homofobia tradicional da sociedade portuguesa se acentuaram quantitativamente, no tom e na intensidade, mas não se alteraram qualitativamente, ou seja, os termos do argumentário anti-homossexual mantiveram-se no essencial e não se regista nada que se pareça com uma vaga persecutória na sequência imediata da epidemia de sida. O que, por outro lado, confirma os traços arcaicos da sociedade portuguesa: 
a comunidade gay não tinha ultrapassado o estádio tradicional de menorização (não é reconhecida como igual, não é sequer reconhecida como interlocutora válida), objectificação (não tem controlo sobre as representações sociais dela e não é sujeito de afirmação ou acção pública), invisibilidade (é destituída de expressão própria, de representantes ou não se lhe associam pessoas nem acontecimentos relevantes) e acomodação (adapta-se, por imperativo de sobrevivência, à situação marginal e clandestina a que se encontra remetida). Isto significa também que, do lado da comunidade gay, a epidemia de sida teve por efeito uma espécie de outing, tanto das pessoas individualmente consideradas (quando afectadas pela doença) como da comunidade em geral. $\mathrm{O}$ associativismo constitui o cerne da resposta de autodefesa da comunidade ao repto que esse outing consubstancia. A epidemia de sida proporcionou a oportunidade para a comunidade gay (e depois GLBT) se erguesse contra antiquíssimas opressões. Com efeito, após o primeiro impacto da sida no nosso país, entre 1984-1986 e 1990-1991, a fase de amadurecimento do associativismo, como reacção àquele impacto, decorre sensivelmente entre 1990-1991 e 1995-1997 e assume uma importância crucial na periodização que propus. É nestes anos (entre 1990 e 1997) que têm lugar as transformações que tenho estado a descrever. Os anos de 90-91 e de 95-97 constituem anos de transição entre os períodos imediatamente anterior e imediatamente posterior, em que, respectivamente, se mantêm características do período antecedente e se esboçam características do período subsequente. E foi a primeira vez que uma situação agónica - em que um pólo hegemónico esmagava a tal ponto o pólo dominado que o própria existência do confronto podia ser por aquele negada - se resolveu a favor da comunidade gay em Portugal, desde o trágico episódio de um confronto semelhante na nossa história do século XX, aquele que opôs António Botto e Judite Teixeira (e, decerto, Fernando Pessoa) à homofobia do Estado Novo (Cascais, 2003a).

Directamente afectada pela sida, a comunidade gay é igualmente aquela que mais se transforma por efeito dela. Acontece que, nos países centrais, a epidemia contribuiu para precipitar uma deslocação fundamental: de uma estratégia de luta pela cidadania sexual centrada na reivindicação de direitos respeitantes à conduta prática (direitos à actividade sexual, ao prazer, ao corpo) e à identidade (direitos à autodefinição, à expressão, à auto-realização) para uma estratégia de luta pela cidadania sexual que enfatiza os direitos respeitantes à relação (direitos ao consentimento, à livre escolha, ao reconhecimento institucional da relação, como a união de facto e o casamento, e direitos conexos, como o acesso à procriação medicamente assistida e à adopção). Concomitante dessa deslocação, ocorrem pelo menos 
três outras mudanças relevantes para nós: mudança de um argumentário predominantemente essencialista para uma tónica construcionista na abordagem das identidades, o que culminará com o pensamento queer; crítica à hegemonia da identidade gay e a consequente fracturação interna das comunidades pela afirmação separatista das identidades lésbica, primeiro, e bissexual e transgénero, logo de seguida (dando origem ao jargão corrente GLBT, sobre cuja real pertinência não me demorarei aqui); mudança da afirmação da diferença, da irredutibilidade e da singularidade da comunidade, que tem o seu expoente no gueto como uma espécie de "zona libertada" autodiscriminatória, seguindo o modelo étnico norte-americano que depois tenderia a exportar-se universalmente, para uma lógica de crescente integração dos estilos de vida específicos, gay, lésbico, bissexual e transgénero que visa esboroar as fronteiras mais ou menos rígidas entre o gueto e a sociedade envolvente - mas que, como já apontava há muito Foucault, é também mais difícil que o entrincheiramento no gueto. Dos modos de vida alternativos que só podem germinar no gueto, ou seja, uma alternativa na diferença, passa-se a uma alternativa na integração, na igualdade, na paridade e na indiferença - caso do casamento e da adopção, que, para gays e lésbicas, constituem a construção de um modo de vida assente na reelaboração daquilo a que Anthony Giddens (1993) chamou a relação pura. No entanto, isto só se tornou possível na sequência de um longo processo de construção das identidades e de consolidação das comunidades GLBT, facto que só ocorre no nosso país de maneira superficial.

O movimento associativo português emerge neste contexto de viragem na cultura e nas identidades das comunidades GLBT a nível internacional, mas, como facilmente pode verificar-se, com compreensíveis dificuldades de assimilação dela. Chegamos, assim, ao último período, que começa a desenhar-se nos anos 1995-1997, triénio de transição na qual se conservam características da fase anterior, e que se encontra plenamente constituído desde aquele último ano, prolongando-se até ao presente.

\section{Terzo - “Allegro Ma Non Troppo e Grazioso"}

$\mathrm{Na}$ periodização que elaborei e à qual deve atribuir-se sobretudo um valor heurístico, a única excepção claramente reconhecível é o GTH, cujos primórdios estão bastante mais próximos do espírito do MHAR e do CHOR que do associativismo posterior a 1995, mas que se diferencia claramente daquelas duas organizações pelo facto de ter surgido no seio de um partido político, o Partido Socialista Revolucionário (PSR), com ideário que começou por se nortear pelo trotskismo. A história do GTH, que se transformaria sucessivamente em Grupo GLBT do Bloco de Esquerda, quando o PSR 
integrou o BE, e em Panteras Rosa - Frente de Combate à Homofobia (2004), já independente de estruturas partidárias, é particularmente ilustrativa de dois factos conexos: de a emancipação homossexual ter sido longamente "empurrada" para a esquerda revolucionária e tender a exprimir-se nos termos radicais da recusa outsider do sistema, em grande medida pela impossibilidade ou a relutância de a homossexualidade "instalada" nas elites sociais, culturais e políticas se afirmar publicamente como tal; de quanto a filiação ou a afinidade político-partidária constitui a nemesis do associativismo e uma razão fundamental da revisão do discurso emancipatório de que falei no início deste ensaio, por mor da necessidade de ultrapassagem do ensimesmamento político-partidário e de não alienar a própria comunidade GLBT que não se reconhece na defesa dos seus interesses nesses termos.

A visibilidade e a consequência do associativismo são precisamente aquilo que constitui, em essência, a terceira e presente fase, desde os anos de 1995-1997, a partir dos quais a comunidade GLBT assume rostos próprios que a representam, se torna num sujeito histórico dotado de voz própria e interlocutor, tanto dos seus aliados como dos seus opositores. Estes são os anos do surgimento explosivo de associações e de iniciativas: a ILGA-Portugal, com a abertura do Centro Comunitário Gay e Lésbico em Lisboa (1997), a Opus Gay (1997) e o Clube Safo (1996), assim como o PortugalGay.PT (1996), organização que desenvolve toda a sua actividade a partir do seu site na Internet, a revista Korpus (1996), primeira publicação a alcançar a longevidade de uma década, o Festival de Cinema Gay e Lésbico de Lisboa, com igual longevidade desde a sua primeira realização em 1997, e o programa radiofónico Vidas Alternativas, desde 1999, caso único de acesso à mediatização no associativismo nacional. É também nestes anos que a esfera político-partidária de esquerda, com representação parlamentar e autárquica, se torna finalmente receptiva às reivindicações da comunidade, facto que culmina com a presidência de João Soares na Câmara Municipal de Lisboa. A receptividade geral e até mesmo a simpatia declarada de alguns meios de comunicação compõem esta conjuntura favorável, que se mantém pelo menos até finais de 2004 e em cujo quadro têm lugar o primeiro Arraial Pride (1997), realizado depois na emblemática Praça do Município de Lisboa, a primeira Marcha do Orgulho (2000), com uma dinâmica de crescimento que se mantém pelo menos até 2002, com a primeira Semana do Orgulho. Subsidiário desta dinâmica de crescimento é a criação, um pouco posterior, de associações tais como a não te prives - Grupo de Defesa dos Direitos Sexuais (2001), a Rede ex aequo (2003), para jovens GLBT entre os 16 e os 30 anos, a @t - Associação para o Estudo e Defesa dos Direitos 
à Identidade de Género (2003), o Grupo Lilás, ou o NÓS - Movimento Universitário para a Liberdade Sexual, entre 2000 e 2003, o Grupo Oeste Gay, entre 2000 e 2005, e a Coisas do Género, entre 2001 e 2003, ou inclusive associações como a Muralha e a Associação Portuguesa de Homossexualidade Masculina (2006), cuja razão de ser fundamental é a demarcação pública do movimento GLBT. Factos a notar absolutamente, são: a expansão do raio de acção das associações para fora dos grandes centros urbanos de Lisboa e do Porto, ou através das actividades que promovem, ou até porque se organizam em rede ou estão mesmo sediadas fora daqueles centros; a diferenciação interna das associações, cujo exemplo mais marcante é o Grupo de Mulheres da ILGA (1998), depois Grupo de Intervenção e Reflexão sobre Lesbianismo (2000); a capacidade de acolhimento de eventos de âmbito supranacional, como a 17. ${ }^{a}$ Conferência Anual da International Lesbian, Gay, Bisexual and Transgender Youth and Student Organisation (2003), pela Rede ex aequo, a 24. ${ }^{a}$ Conferência Anual da ILGA-Europa (2002), pela Opus Gay, e o lançamento do Dia Mundial de Luta Contra a Homofobia (2005), com a presença do seu criador, Louis-Georges Tin, por iniciativa da Associação Janela Indiscreta, que entretanto se formalizou como organizadora do Festival de Cinema Gay e Lésbico de Lisboa; o reconhecimento do associativismo pelos representantes nacionais de organizações mundiais, como o Núcleo Mulheres e LGBT da Secção Portuguesa da Amnistia Internacional, assim como a participação activa das associações nacionais em eventos de alcance internacional, como a edição nacional da Marcha Mundial das Mulheres (2000) e o Primeiro Fórum Social Português (2003); embora ainda escassa articulação com a reflexão e a investigação académica, ensaiada com êxito pelo Clube Safo, que co-organizou com o Instituto Superior de Psicologia Aplicada as primeiras Jornadas Lésbicas (2002) e o primeiro Congresso Internacional de Estudos Gay, Lésbicos e Queer "Culturas, Visibilidades, Identidades” (2005), promovido conjuntamente pela Associação Janela Indiscreta, o Instituto Franco-Português e o Centro de Estudos de Comunicação e Linguagens da Universidade Nova de Lisboa, para além das iniciativas dinamizadas pela não te prives em colaboração com o Centro de Estudos Sociais da Universidade de Coimbra; last not least, as associações GLBT nacionais tornaram-se interlocutoras privilegiadas das organizações político-partidárias e das instâncias governamentais na elaboração de iniciativas legislativas, embora tivessem - e continuem a ter - de contrariar o paternalismo delas com a definição de agendas próprias, de que constitui exemplo marcante o recente (2005) lançamento da campanha pelo direito ao casamento. 
Se neste período se podem contar algumas significativas conquistas do movimento associativo GLBT, expressas nomeadamente em termos de adquirido jurídico, nem por isso a convergência única de interesses da comunidade GLBT e de interesses político-institucionais deixou de se interromper, o que desmente a sua irreversibilidade. Com efeito, a dinâmica emancipatória mantém-se até ao presente, mas confronta-se com dois factos: o associativismo atinge aquilo que tudo indica ser um limite de crescimento, o qual, por sua vez, é contemporâneo (mas não efeito) do início de uma reacção anti-emancipatória e de um ambiente político e mediático adverso que configuram uma nova situação agónica, não sem certas similitudes com aquela que o precipitou.

Perante as interpelações levantadas pela presente situação, coloca-se ao movimento associativo uma dupla necessidade, que é tanto cognitiva como política: a de conhecer a fundo a comunidade que representa ou de que emerge, com a sua história, a sua identidade, a sua cultura, mas também a sua homofobia internalizada e as formas em que ela se exprime em detrimento do próprio associativismo, reconstruindo uma memória como resistência ao impulso de não-inscrição (Gil, 2004) tão fatal na sociedade e na cultura portuguesa; e a de (re)conhecer os seus detractores e inimigos, antigos e neófitos, tanto mais que eles se definem doravante em função da sua visibilidade e das suas conquistas.

\section{Considerações finais}

O associativismo não se fez do dia para a noite, nem em Portugal, nem em parte nenhuma. Não irrompeu numa tabula rasa histórica, social e cultural. Em Portugal, o associativismo, assim como todas as expressões das culturas e das identidades GLBT, confrontam-se com uma história de opressão, de negação, de controlo social, que deu forma às características da formação social portuguesa que lhes são adversas.

O seu estudo apresenta-se como um primeiro desafio à reflexão gay, lésbica e queer, e bem assim às ciências sociais e humanas para as quais estes fenómenos continuam a constituir, em grande medida, uma autêntica terra incognita. Como o continua a ser o outro património histórico de que as actuais comunidades GLBT são herdeiras directas, mas que há que reconstituir, recuperar e restituir: as expressões culturais gay e lésbica, tanto eruditas como populares que se foram sucedendo ao longo do tempo, as formas de sociabilidade, os léxicos eróticos e as modalidades de "uso dos prazeres" que se sedimentaram historicamente. Este é um segundo desafio maior à teoria gay, lésbica e queer. Os frutos desse trabalho deveriam constituir uma aquisição inestimável para os protagonistas do associativismo GLBT no 
nosso País. A sócio-história deste, nas últimas quatro décadas, é o outro grande desafio cognitivo para que o presente artigo pretende constituir um primeiro contributo.

Dele pode concluir-se, muito sucintamente, que o associativismo GLBT não teria pura e simplesmente sido possível antes da instauração do regime democrático, em 1974, mas que este, por si só, não foi condição suficiente para a sua emergência, a qual, na sociedade semiperiférica portuguesa, levou cerca de três décadas a amadurecer. A sociogénese do movimento GLBT obedece ao padrão comum aos países da Europa do Sul, ocorrendo no seio da tradição e com os materiais do património emancipatório das esquerdas. Embora apropriando-se dele como seu, as incipientes expressões de um movimento organizativo gay e lésbico defrontaram-se com barreiras intransponíveis a uma organização autónoma, a apoios políticos declarados e à inclusão dos seus conteúdos nas agendas das forças político-partidárias e sindicais até ao início da década de 1990.

O processo de reformulação do discurso político que tornou a emancipação gay e lésbica finalmente assimilável por essas forças ocorreu paralelamente, e foi condicionado, pelo cavaquismo (maioria absoluta do PSD em 1987), pela adesão à União Europeia (adesão oficial em 1986), e pela epidemia de sida (detecção dos primeiros casos em 1984-85), ou seja, e respectivamente: pela modernização das esquerdas político-partidárias e culturais numa situação de defensiva, pela substituição do modelo revolucionário de mudança social por expectativas de acesso ao adquirido económico, social e jurídico-político europeu e comunitário e pelo enquadramento dos segmentos da comunidade gay directamente afectados pela epidemia de sida e que nada tinham a perder, mas que envolveu, necessariamente, organizações não-governamentais de luta contra a sida, que lhes proporcionaram as necessárias dinâmica e legitimidade.

O associativismo GLBT em Portugal ganha pois impulso no seio de um processo mais vasto de combate à epidemia de sida, em cuja dinâmica começa por se integrar, dela tirando partido de forma notável, antes de poder vir a autonomizar-se dela, constituindo a sua própria dinâmica. Nesta medida, a sociogénese do associativismo GLBT confirma a situação de semiperiferia da formação social portuguesa. É esta situação que explica que só a partir da segunda metade da década de 1990 o associativismo GLBT português adquira expressão idêntica aos seus congéneres europeus e norte-americanos, traduzida em organizações com representatividade no seio da própria comunidade, visibilidade social e mediática, credibilidade e capacidade de pressão sobre os organismos político-partidários e as instituições do Estado, e enfim, uma agenda política própria. 


\section{Referências bibliográficas}

Almeida, Miguel Vale de (2004), Outros destinos. Ensaios de Antropologia e cidadania. Porto: Campo das Letras.

Amaral, Ana Luísa; Moita, Gabriela (2004), "Como se faz (e se desfaz) o armário: Algumas representações da homossexualidade no Portugal de hoje”, in António Fernando Cascais (org.), Indisciplinar a teoria. Estudos gays, lésbicos e queer. Lisboa: Fenda, 99-115.

Cascais, António Fernando (1983), “Como quem não quer a coisa”, Fenda (In)Finda, 7, 9-17.

Cascais, António Fernando (1988), "Autenticidade e razão decisória em Michel Foucault”, Revista de Comunicação e Linguagens, 6/7, 71-83.

Cascais, António Fernando (1994), "Paixão, morte e ressurreição do sujeito em Michel Foucault", Revista de Comunicação e Linguagens, 19, 77-117.

Cascais, António Fernando (1997), "Da virulência", prefácio a António Fernando Cascais (org.), A Sida por um fio. Lisboa: Editorial Vega, 7-25.

Cascais, António Fernando (2003a), "Portugal", in Georges-Louis Tin (org.), Dictionnaire de l'homophobie. Paris: Presses Universitaires de France, 328-330.

Cascais, António Fernando (2003b), "Sexo para que te quero?", Interact. Revista Online de Arte, Cultura e Tecnologia, 9. Disponível em: http://www.interact.com.pt.

Cascais, António Fernando (2004), "Um nome que seja seu: Dos estudos gays e lésbicos à teoria queer", in António Fernando Cascais (org.), Indisciplinar a teoria. Estudos gays, lésbicos e queer. Lisboa: Fenda, 21-89.

Foucault, Michel (1977), História da sexualidade, 1: A vontade de saber. Lisboa: Edições António Ramos.

Giddens, Anthony (1993), The Transformation of Intimacy. Sexuality, Love and Eroticism in Modern Societies. Cambridge: Polity Press.

Gil, José (2004), Portugal, hoje. O medo de existir. Lisboa: Relógio d'Água.

Lourenço, Eduardo (1978), O labirinto da saudade. Psicanálise mítica do destino português. Lisboa: Publicações Dom Quixote.

Mira, Alberto (2004), De Sodoma a Chueca. Barcelona: EGALES.

Santos, Ana Cristina (2005), A lei do desejo. Direitos bumanos e minorias sexuais em Portugal. Porto: Afrontamento.

Santos, Boaventura de Sousa (1992), O Estado e a sociedade em Portugal (1974-1988). Porto: Afrontamento.

Santos, Boaventura de Sousa (1996), Pela mão de Alice. O social e o político na pós-modernidade. Porto: Afrontamento. 